\title{
ESG-finance principles as the key drivers of Russian regions' investment potential
}

\author{
Daria Egorova
}

Financial University under the Government of the Russian Federation, Leningradsky prospect, 49, 125993 Moscow, Russia

\begin{abstract}
This article presents an analysis of challenges and prospects for the development of responsible investment in Russia and gives a detailed description of the ESG-finance principles (ESG - Environmental, Social, Governance). The new economic conditions cause necessity to search the new methodology approaches in different theoretical fields. The author gives a wide summary of approaches to precise an investment potential of the regions in Russia and makes a conclusion that all of the existing assessment tools are not perfect and need to be improved. Such an enhancement could be based on the results of the a pairwise correlation analysis: the author considers data sampling for all the regions of the Russian Federation and tests it with four indicators: the investment activity of the region, as a resulting indicator; environmental protection costs, the number of companies disclosing non-financial reporting and percentage of companies in the region implementing innovations in the framework of energy conservation, as factors in assessing the investment potential of the region.
\end{abstract}

\section{Introduction}

It would be no an exaggeration to say that the global challenge and the main strategic goal for over the last decade is the transfer to the "green" economy. The World Wildlife Fund defines the "green" economy as an inclusive system, characterized by efficient usage of resources and minimization of hydrocarbons' explosion, growth of employment and income, ensured by investments, reduction of carbon dioxide emissions, increase of resource and energy efficiency and prevention of a further decrease in biodiversity and ecosystem services [1].

The "green" transformation process in the world economy is impossible without the wide implementation of ESG-finance principles. ESG-finance principles stand for: Environmental, Social, Governance factors, which are to be included into the business processes worldwide to reach the target of changing the pattern and turning to the ecofriendly economy [2].

It's necessary to consider the following ESG-finance principles (Principles):

- inclusion of environmental, social aspects and management issues into the investment analysis and decision-making process of companies;

- $\quad$ proper disclosure of non-financial information such as environmental, social and management issues, involved in the investment activities of companies; 
- popularization of the Principles' implementation in the companies' investment activities by the government and public authority;

- promoting the results, achieved in the implementation of the Principles by the government and public authority.

The implementation of ESG-finance principles within the investment activities is called the responsible investments. The most important spheres of responsible investments worldwide are: renewable energy, energy-efficient solutions, "green" technology, the production with low carbon emission, creation of closed water systems, increasing resource efficiency.

\subsection{Perspectives of ESG-finance principles' implementation in Russia}

The pronounced "Year of Ecology" in 2017 was the starting point for active "green" transformation for the Russian economy $[3,4]$. The capacity of the green economy in Russia is determined by at least three most important factors [5]:

1. The introduction of a carbon tax in accordance with the Paris Agreement of the United Nations Framework Convention. The volume of tax revenues by 2020 in Russia could reach the amount of 1 trillion. rub.

2. The need to create the infrastructure of the waste processing industry by 2020 is estimated at 150 billion rubles.

3. The internal energy efficiency of housing and communal services requires about 100 billion euros in the next 20 years.

Thus, for the "green" transformation of the Russian economy, according to experts, long-term investments of about 6 billion euros are required annually. However, due to the specifics of Russian industry and the large share of its unprofitable areas, the amount of required investments could significantly exceed.

In Russia issues of responsible investment, including its environmental component, are currently under the responsibility of the following regulators: The Ministry of Economic Development, The Ministry of Natural Resources and Ecology of Russia, the Working Group on Responsible Financing (ESG-finance) as part of the Expert Council on long-term investment market under the Bank of Russia.

\subsection{Responsible investment as a part of investment potential of the Russian region}

The identification of the region's investment attractiveness and investment potential seems to be incomplete without the precision of ESG-finance principles' usage degree. This could be explained by the territorial length of the country, the remoteness of some administrative units, the difference in climatic and environmental conditions, principles of local management.

Thus, in author's opinion, it's vital to include the ESG-finance principles as factors of the region's investment attractiveness and investment potential in the existing assessment methodology. To prove this statement author checks the correlation between the chosen factors within ESG-finance concept and the amount of investments in the Russian regions.

\section{Methods}

\subsection{Methods of regions' investment potential assessment}


Let's consider the existing methods of determination of the Russian regions' investment potential.

The term "investment potential" is considered quite comprehensively, while you cannot identify it with the terms "investment attractiveness" and "investment activity". Table 1 presents a comparative analysis of approaches to the definition of the term "investment potential of the region".

Table 1. Comparative analysis of approaches to the definition of the concept of "investment potential of the region"

\begin{tabular}{|l|l|l|}
\hline $\begin{array}{c}\text { No.p } \\
\text { /p }\end{array}$ & \multicolumn{1}{|c|}{ Authors } & \multicolumn{1}{c|}{ Definition } \\
\hline $\mathbf{1}$ & N.D. Guskova & $\begin{array}{l}\text { When assessing the investment potential, } \\
\text { macroeconomic factors, the provision of the territory } \\
\text { with production factors, and consumer demand are } \\
\text { taken into account. }\end{array}$ \\
\hline $\mathbf{2}$ & $\begin{array}{l}\text { IN AND. Afonin } \\
\text { L.S. Valinurova } \\
\text { ABOUT. Kazakova }\end{array}$ & $\begin{array}{l}\text { Investment potential is a set of resources, including } \\
\text { natural-material, financial and intangible assets. }\end{array}$ \\
\hline $\mathbf{3}$ & R.N. Malyshev & $\begin{array}{l}\text { The investment potential of the region includes the } \\
\text { following elements: industry indicators, the composition } \\
\text { of financial investments in the company's fixed assets, } \\
\text { the index of the physical volume of investments in fixed } \\
\text { assets, the duration of the reporting period, the } \\
\text { depreciation rate, the composition of foreign direct } \\
\text { investment, profitability indicators }\end{array}$ \\
\hline $\mathbf{4}$ & $\begin{array}{l}\text { R.A. Karmov } \\
\text { Investment potential is a set of own resources intended } \\
\text { for accumulation and allowing to achieve the expected } \\
\text { result when using them. }\end{array}$ \\
\hline $\mathbf{5}$ & $\begin{array}{l}\text { T.V. Borovikova } \\
\text { G.V. Zakharova } \\
\text { N.V. Kiseleva } \\
\text { I.B. Maximov } \\
\text { T. Nenakhova }\end{array}$ & $\begin{array}{l}\text { Investment potential is the ability of the regional } \\
\text { economy to achieve maximum results in the given } \\
\text { conditions. }\end{array}$ \\
\hline
\end{tabular}

Source: compiled by the author based on $[6,7,8,9]$

The assessment of the investment potential of the region is very important for all interested parties, especially for potential investors, since the results of such an assessment make it possible to determine the most effective objects for investment, as well as the strengths and weaknesses of the region, which forms the final efficiency of investment activities.

According to the research of the National Rating Agency [10], most of the regions of the Russian Federation are potentially attractive for investors.

It is worth noting that the specific gravity of 25 regions whose investment attractiveness is rated as "high" in the rating of the National Rating Agency [10] is about $86 \%$. At the same time, 27 regions with "moderate" investment attractiveness accounted for only less than $2 \%$ of foreign direct investment inflows and less than $9 \%$ of fixed capital investment. In almost all the regions assigned to the lowest rating category IC9, foreign investment is completely absent.

It's necessary to mention that there is a frequent lack of a direct link between the investment activity of the region and its calculated investment potential. This circumstance can be explained by the fact that the methodology of region's investment potential assessing often does not include the subjective interests of stakeholders, so the potential investormay revaluate investment risks in the region and undervalue its investment potential. 
Thus, the methodology of region's investment potential assessing should include not only objective factors, such as the commercial effectiveness of investment projects implemented in the region, as well as state support for investment initiatives, but also, for example, achievement of social, innovative and environmental goals.

Among the native and foreign methods of the region's investment potential assessing, we have identified the following:

- Methodology of the Council for the Study of Production Forces of the Ministry of Economic Development;

- Methodology of the Russian Expert Agency;

- Methodology of the Forbes magazine.

Each of these methods is based on the analysis of the most important factors for the development of the region: production, financial, social and environmental. In more detail, the factors included in each of these methods are listed in table 2.

Table 2. Comparative characteristics of methods for assessing the effectiveness of the region's investment potential

\begin{tabular}{|l|l|l|l|}
\hline $\begin{array}{l}\text { No. } \\
\mathbf{p} \\
\mathbf{p}\end{array}$ & $\begin{array}{l}\text { Methodology of the Council } \\
\text { for the Study of Production } \\
\text { forces of the Ministry of } \\
\text { Economic Development }\end{array}$ & $\begin{array}{c}\text { Agency Methodology } \\
\text { "Expert" }\end{array}$ & \multicolumn{1}{|c|}{$\begin{array}{c}\text { Journal technique } \\
\text { "Forbes" }\end{array}$} \\
\hline 1 & Share of the poor & Consumer potential & Social chara cteristics \\
\hline 2 & $\begin{array}{l}\text { The level of conflict in labor } \\
\text { relations }\end{array}$ & Resource potential & Business climate \\
\hline 3 & Crime level & Financial potential & Infrastructure \\
\hline 4 & Unemployment rate & Production potential & $\begin{array}{l}\text { Purchasing power of the } \\
\text { population }\end{array}$ \\
\hline 5 & Environmental pollution & Infrastructure potential & Crisis resistance \\
\hline 6 & The attitude of the population & Labor potential & Comfort \\
\cline { 3 - 3 } to the processes of formation \\
\cline { 3 - 3 } of a market economy & innovative potential & \\
\cline { 3 - 3 } & & Institutional capacity & \\
\hline 8 & & &
\end{tabular}

Let's analyze the advantages and disadvantages of the considered methods. All methods could be implemented in practice, and this fact is their indisputable advantage/ Also we can highlight the following strengths of the considered approaches:

- The expert agency methodology compares investment potential with investment risks;

- The Forbes methodology includes in the assessment indicators, characterizing the regional economy, and also forms a rating of regions, which reflects the position of the region relative to others in terms of investment attractiveness;

- The methodology of the Council for the Study of the Production Forces of the Ministry of Economic Development is distinguished by the identification of the relationship between investment activity and the attractiveness of the region using statistical tools.

Among the obvious shortcomings of the mentioned methods, experts call the following:

- $\quad$ subjectivity of the choice of factors;

- lack of linkage between investment potential and investment activity;

- low transparency of the assessment.

In the framework of this article, we propose to adjust the existing valuation techniques by considering the factors that form the region's investment potential and taking into 
account the identified correlation between the proposed factors and the region's investment activity as the expected result of achieving a satisfactory investment potential.

\section{Results}

As the resulting indicator, we took the investment activity of the regions of Russia.

Next, we considered factors that are not used in existing methods for assessing the region's investment potential:

- the number of companies operating in the region that disclose non-financial information;

- the number of companies operating in the region that introduce innovations aimed at resource efficiency;

- the environmental costs.

So, as a result of the analytical research work of the Technical Expert Group, created within the framework of the European Commission, it was concluded that in international practice one of the key factors in choosing an investment object is the completeness of disclosure of information on non-financial risks and opportunities related in particular to climate change, which directly indicates the development of responsible investment in foreign practice.

Full disclosure of non-financial information can help to ensure a lower cost of capital and a more diverse investor base. In addition, increasing confidence in the disclosure of non-financial information can support "green" bonds and stimulate innovation in responsible investment strategies in the wider financial ecosystem (Fig. 6) [5].

In accordance with the Government Order [3], from 2019, a requirement has been established for the mandatory publication of non-financial reports for companies with state participation of at least $50 \%$. The regulator responsible for the implementation of this order is the Department of Financial Banking and Investment Development of the Ministry of Economic Development of the Russian Federation. State standard R ISO 26000-2012 fixes the composition and forms of non-financial reports.

However, not all the companies, which activities are directly related to environmental impacts and are subject to corresponding risks, present non-financial reports. Today the major challenge is to convey to all stakeholders the importance and significance of nonfinancial information disclosure.

As of January 2019, 176 companies have been entered into the National Register. Since 2000924 reports have been issued and registered. Among them: environmental reports - 82, social reports - 326, reports in the field of sustainable development - 314, integrated reports - 174, industry reports - 27. According to the results of 2017 and 2018, 88 organizations were entered into the National Register, 166 reports were issued and registered ( 77 reports in 2017, 89 reports - in 2018).

If we analyze the dynamics retrospectively, small "bursts" of activity are clearly visible sequentially in 2007, 2011 and 2013, which could be associated with the implementation of industry projects, requesting non-financial reporting (in electricity, nuclear and chemical industries).

Moreover, until 2010, the growth rate was quite high (the number of reports increased by $50-100 \%$ per year). Since 2011 , the process has slowed down: the increase in the number of published reports has been $10-15 \%$ per year, and since 2014 - only $2-4 \%$ per year, which means that there are fewer new companies joining the public reporting processes than in the optimistic period until 2010.

According to the analysis of PricewaterhouseCoopers [11]: 
- the companies see the value of certifying of non-financial information as a step towards strengthening the relationships between stakeholders;

- $\quad$ in Russia, the number of companies certifying their non-financial information is lower than the global average;

- The Federal Law "On the public non-financial reporting "is believed to have a significant impact on the quantity and quality of such reporting.

The next most important factor in assessing of region's investment potential is the amount of environmental protection costs. In the previously considered methodology of determining the region's investment potential, developed by the Council for the Study of the Production Forces of the Ministry of Economic Development, one of the factors is the level of environmental pollution.

In our view, this factor is not always indicative for the evaluation of the region's investment potential due to the specifics of territorial spread, and also a big difference in the security of the regions by natural resources in Russia.

At the same time, it is environmental protection costs that characterize the degree of responsibility for maintaining a satisfactory environmental situation within the region and could be a factor in the assessing approach of the region's investment potential for an investor.

Innovations aimed at energy efficiency, energy saving, optimal consumption of natural resources and reduction of negative environmental impact that are implemented by companies in the region can also be considered as a factor in the assessing approach of the region's investment potential.

We considered data sampling for all the regions of the Russian Federation and tested it with four indicators: the investment activity of the region, as a resulting indicator; environmental protection costs, the number of companies disclosing nonfinancial reporting and percentage of companies in the region implementing innovations in the framework of energy conservation, as factors in assessing the investment potential of the region.

To verify the relationship of the considered indicators, a pairwise correlation analysis was carried out, the results of the analysis are presented in table 3.

Table 3. The degree of influence of factors on the investment activity of the regions of the Russian Federation

\begin{tabular}{|c|l|c|}
\hline $\begin{array}{c}\text { No. } \\
\mathbf{p} / \mathbf{p}\end{array}$ & \multicolumn{1}{|c|}{ Factor } & $\begin{array}{c}\text { Correlation with the } \\
\text { investment activity of the } \\
\text { region }\end{array}$ \\
\hline $\mathbf{1}$ & Environmental costs & 0.9863877 \\
\hline $\mathbf{2}$ & Number of companies disclosing non-financial reporting & 0.9370986 \\
\hline $\mathbf{3}$ & $\begin{array}{l}\text { \% of companies implementing innovations in the } \\
\text { framework of energy conservation }\end{array}$ & 0,0248578 \\
\hline
\end{tabular}

Thus, we have identified a strong relationship between indicators:

- investment activity of the region and environmental protection costs;

- investment activity of the region and the number of companies that disclose nonfinancial reporting.

Implicit relationship was found between indicators:

- investment activity in the region and percentage of companies implementing innovations in the framework of energy conservation. 
Therefore, we propose to supplement the existing methods of the region's investment potential assessing with two factors that are most important for investment activity: the amount of funds allocated by the region to protect the environment, and the degree of disclosure of non-financial reporting in the region, expressed through the number of companies that provide non-financial reports in accordance with Russian legislation.

\section{Conclusion}

Thus, the "green" transformation of the Russian economy should be based on the implementation of ESG-finance principles in common, and responsible investment in particular. The investment potential of the region is also to be assessed considering these principles. Today we can talk about a shift in the interests of investors towards environmental and ecological projects, as well as companies that take measures to reduce negative impact on the environment and disclose information about their activities in nonfinancial reports. The revealed correlation between investment activity, environmental costs and the number of companies in the region that disclose non-financial reporting allows us to conclude that it is necessary to adjust existing methods for assessing the region's investment potential and include the mentioned factors (environmental costs and the number of companies in the region that disclose non-financial reporting) into these methods.

\section{References}

1. Diagnostic note "Green Finance: an agenda for Russia", https://www.cbr.ru/

2. The official website of the National Association of concessionaires and long-term investors in infrastructure, https://investinfra.ru/

3. Decree of the President of the Russian Federation of August 1, 2015 No. 392 "On the Year of Specially Protected Natural Territories in the Russian Federation", http://base.consultant.ru

4. Decree of the President of the Russian Federation of January 5, 2016 No. 7 "On the Year of the Environment in the Russian Federation", http://base.consultant.ru

5. Report of the Panel of Technical Experts on Disclosure of Financial Information Associated with Climate Change - Report on Climate-related Disclosures, ttps://ec.europa.eu/

6. ND. Guskova, I.N. Krasovskaya, Yu.Yu. Slushkina, V.I. Makolov, Investment managemen, 440 (2014)

7. L.S. Valianurova, O.B. Kazakova, Investing: a textbook for high schools, 448 (2010)

8. Malyshev R.N., The investment potential of the state in the economy of modern Russia (2007)

9. N.V. Kiseleva, T.V. Borovikova, G.V. Zakharova, Investment activity (2006)

10. Investment attractiveness of the regions of Russia, http://www.ra-national.ru/

11. ESG factors in investing, https://www.pwc.ru/

12. The official website of the Federal State Statistics Service, https://www.gks.ru/ 